\title{
Variations in Awareness of Association Between Adverse Pregnancy Outcomes and Cardiovascular Risk by Specialty
}

\author{
Venkata Sai M. Gogineni - Denise Manfrini - Sharon H. Aroda • \\ Yahan Zhang · Danielle S. Nelson · Robert Egerman · Ki Park
}

Received: November 25, 2020 / Published online: May 27, 2021

(C) The Author(s) 2021

\begin{abstract}
Introduction: Cardiovascular disease (CVD) remains the leading cause of death among women. Adverse pregnancy outcomes (APOs), including pre-eclampsia (PE), gestational diabetes mellitus (GDM) and pre-term birth (PTB) are associated with future maternal CVD risk. However, data on awareness of the association between APOs and long-term CVD risk among physicians in different specialties are lacking.
\end{abstract}

V. S. M. Gogineni · S. H. Aroda

Department of Internal Medicine, University of Florida, Gainesville, FL, USA

D. Manfrini

University of Florida College of Medicine, Gainesville, FL, USA

Y. Zhang

Department of Pharmaceutical Outcomes and Policy, College of Pharmacy, University of Florida, Gainesville, FL, USA

D. S. Nelson

Department of Community Health and Family

Medicine, University of Florida, Gainesville, FL, USA

R. Egerman

Department of Obstetrics and Gynecology,

University of Florida, Gainesville, FL, USA

K. Park $(\square)$

Division of Cardiovascular Medicine, University of Florida, Gainesville, FL, USA

e-mail: ki.park@medicine.ufl.edu
This study assessed awareness of this association and whether this knowledge varies by specialty. Methods: An anonymous web-based voluntary survey was sent to physicians in internal medicine (IM), family medicine (FM), obstetrics-gynecology (Ob-Gyn) and cardiology. The questions aimed to assess a physician's knowledge regarding identification of APOs and their association with future CVD risk and knowledge of CVD risk factor screening in women with APOs and future CVD risk.

Results: The survey was completed by 53 physicians, of whom $21 \%$ were in IM, $26 \%$ in FM, 23\% in Ob-Gyn and 30\% in cardiology. Based on the responses, cardiologists screened most frequently for APOs, with 56\% always screening a female patient and $31 \%$ often screening. Only half of the IM and FM physicians acknowledged awareness of the association between APOs and CVD risk. Respondents in all specialties recognized PE and GDM as APOs linked to long-term maternal CVD risk, but failed to associate PTB as an APO. The majority of physicians in IM, FM and cardiology also lacked the knowledge of how often to appropriately screen for CVD risk factors associated with APOs.

Conclusion: Awareness of the association between APO and future maternal CVD risk varies by specialty. A significant percentage of the physicians who responded to the survey did not routinely ask about APOs when assessing CVD risk and failed to identify PTB as a risk 
factor for APOs. Education on this topic and targeted efforts to improve screening for APOs are needed within all specialties to help reduce CVD morbidity and mortality.

Keywords: Adverse pregnancy outcomes; Preeclampsia; Cardiovascular disease; Risk reduction; Primary prevention

\section{Key Summary Points}

Why carry out this study?

Adverse pregnancy outcomes (APOs) are associated with risk of long-term cardiovascular disease (CVD). However, how awareness of such association varies by specialties is unknown.

What did the study ask?/What was the hypothesis of the study?

We assessed awareness of APO and CVD risk among physicians in various medical specialties via a voluntary survey, with the hypothesis that awareness would vary by specialty type.

\section{What were the study outcomes/conclusions?}

Providers from all specialties reported varying degrees of routinely screening their female patients for CVD risk factors, with cardiologists screening most frequently (56\% all women and 31\% often screening).

Only half of the IM and FM providers who responded to the survey acknowledged awareness of the association between APOs and CVD risk in women compared with the vast majority of providers in the fields of obstetrics-gynecology and cardiology.

The majority of providers in IM, FM and cardiology did not ask about APOs and lacked the knowledge of how often to appropriately screen for CVD risk factors associated with APOs.

\section{DIGITAL FEATURES}

This article is published with digital features, including a summary slide, to facilitate understanding of the article. To view digital features for this article go to https://doi.org/10.6084/ m9.figshare.14554209.

\section{INTRODUCTION}

Cardiovascular disease (CVD) remains the number one cause of death among women [1-3]. Much effort has been expended during the past decade to reduce both the incidence and prevalence of this disease burden through screening and treating nontraditional risk factors in women. Contemporary studies have shown that adverse pregnancy outcomes (APOs), including pre-eclampsia (PE), gestational diabetes mellitus (GDM) and pre-term birth (PTB), are associated with future maternal CVD risk [1, 4, 5, 11-13]. To what degree these associations are known among medical physicians and how that varies by specialty is limited. Additionally, much of the current literature focuses mostly on awareness of $\mathrm{PE}$ as a risk factor for chronic hypertension and CVD. The aim of this study was to perform a more comprehensive assessment, including other APOs, and determine whether physicians in various specialties at our institution are aware of the association between APO and CVD risk and how this awareness may vary by specialty.

\section{METHODS}

An anonymous web-based voluntary survey comprising 11 questions (Table 1) was sent to physicians in the fields of internal medicine (IM), family medicine (FM), obstetrics-gynecology (Ob-Gyn) and cardiology at the University of Florida (UF Health). All physicians (MD [allopathic doctor)] or DO [osteopathic doctor]) who were employed by UF Health and worked in the departments of IM, FM, Ob-Gyn and cardiology were eligible to participate. This was purely a voluntary study, and participants had the option of withdrawing at any time. This 
Table 1 Survey of questions and answer options sent to providers

Question Question
number

$1 \quad$ How long are you in practice?

$<5$ years, $5-10$ years,

$11-20$ years, $>20$ years

2 What is your sex?

Male, Female

3 What proportion of your patients are women?

$100 \%, 50-100 \%$, Less than $50 \%$, Less than $25 \%$

4

Do you routinely screen your women patients for cardiovascular risk factors?

Every Woman, Often, Sometimes, Never

5 When assessing cardiovascular risk in women, do you ask about adverse pregnancy outcomes?

Every Woman, Often, Sometimes, Never

6

Are you aware of the association between adverse pregnancy outcomes and cardiovascular risk in women?

Yes, No

$7 \quad$ Which of the following is an adverse pregnancy outcome associated w/maternal long-term cardiovascular risk? May choose more than one.

Pre-eclampsia, Cervical Insufficiency, Gestational Diabetes Mellitus, Preterm

Birth, Post-partum hemorrhage

8

How often should women with a history of gestational diabetes be screened for diabetes after delivery?

Every 5 years, Every 3 years, Every 1 year, I don't know
Table 1 continued

\begin{tabular}{ll}
\hline $\begin{array}{l}\text { Question } \\
\text { number }\end{array}$ & Question \\
\hline 9 & $\begin{array}{l}\text { Women with history of pre-eclampsia } \\
\text { should have annual assessment of which } \\
\text { of the following? May choose more than } \\
\text { one. }\end{array}$
\end{tabular}

Lipid Profile, Blood Pressure, BMI, Glucose, Annual Mammogram

10
Women with a history of pre-eclampsia have an increased risk of developing which of the following? May choose more than one.

Type 2 Diabetes Mellitus, Ischemic Heart Disease, Chronic Hypertension, Stroke, Heart Failure, Arrhythmia, Syncope

How familiar are you with the current AHA guidelines and/or ACOG guidelines concerning treatment and follow-up management of women with pre-eclampsia?

Very familiar, Slightly familiar, Not at all familiar

Text in bold are pre-specified responses that are based on the most recent American Heart Association (AHA) and American College of Obstetricians and Gynecologists (ACOG) guidelines [13-16]

project was approved as a quality improvement project with the Institutional Review Board at the University of Florida. The survey consisted of demographic questions and practice characteristics (Questions 1-6 and 11) and of questions that aimed to assess a physician's knowledge on the identification of APOs and their association with future CVD risk. Finally, the survey elicited physician knowledge about screening frequencies, future complications and follow-up (Questions 7-10); these questions had pre-specified responses (shown in bold in 
Table 2 Demographics and provider characteristics

\begin{tabular}{|c|c|c|c|c|c|c|c|c|c|}
\hline \multirow{2}{*}{$\begin{array}{l}\text { What is your } \\
\text { specialty? } \\
N(\%)\end{array}$} & \multicolumn{2}{|l|}{ Question 1} & \multirow[t]{2}{*}{$p$ value } & \multicolumn{2}{|c|}{ Question 2} & \multirow[t]{2}{*}{$p$ value } & \multicolumn{2}{|c|}{ Question 3} & \multirow[t]{2}{*}{$P$-value } \\
\hline & \multicolumn{2}{|c|}{$\begin{array}{l}\text { How long are you in } \\
\text { practice? }\end{array}$} & & \multicolumn{2}{|c|}{ What is your sex? } & & \multicolumn{2}{|c|}{$\begin{array}{l}\text { What portion of your } \\
\text { patients are women? }\end{array}$} & \\
\hline $\begin{array}{l}\text { Internal } \\
\text { medicine }\end{array}$ & $<5$ years & $5(45.5 \%)$ & 0.079 & Male & $3(27.3 \%)$ & 0.092 & $100 \%$ & $0(0.0 \%)$ & $<0.0001$ \\
\hline \multirow[t]{3}{*}{$11(20.7 \%)$} & $5-10$ years & $0(0.0 \%)$ & & Female & $8(72.7 \%)$ & & $50-100 \%$ & $7(63.6 \%)$ & \\
\hline & $11-20$ years & $2(18.2 \%)$ & & & & & $\begin{array}{l}\text { Less than } \\
50 \%\end{array}$ & $3(27.3 \%)$ & \\
\hline & $>20$ years & $4(36.4 \%)$ & & & & & $\begin{array}{l}\text { Less than } \\
25 \%\end{array}$ & $1(9.1 \%)$ & \\
\hline Family medicine & $<5$ years & $2(14.3 \%)$ & & Male & $7(50.0 \%)$ & & $100 \%$ & $0(0.0 \%)$ & \\
\hline \multirow[t]{3}{*}{$14(26.4 \%)$} & $5-10$ years & $3(27.3 \%)$ & & Female & $7(50.0 \%)$ & & $50-100 \%$ & $13(92.9 \%)$ & \\
\hline & $11-20$ years & $3(27.3 \%)$ & & & & & $\begin{array}{l}\text { Less than } \\
50 \%\end{array}$ & $1(7.1 \%)$ & \\
\hline & $>20$ years & $6(42.9 \%)$ & & & & & $\begin{array}{l}\text { Less than } \\
25 \%\end{array}$ & $0(0.0 \%)$ & \\
\hline OB-Gyn & $<5$ years & $0(0.0 \%)$ & & Male & $5(41.7 \%)$ & & $100 \%$ & $11(91.7 \%)$ & \\
\hline \multirow[t]{3}{*}{$12(22.6 \%)$} & $5-10$ years & $1(8.3 \%)$ & & Female & $7(58.3 \%)$ & & $50-100 \%$ & $1(8.3 \%)$ & \\
\hline & $11-20$ years & $5(41.7 \%)$ & & & & & $\begin{array}{l}\text { Less than } \\
50 \%\end{array}$ & $0(0.0 \%)$ & \\
\hline & $>20$ years & $6(50.0 \%)$ & & & & & $\begin{array}{l}\text { Less than } \\
25 \%\end{array}$ & $0(0.0 \%)$ & \\
\hline Cardiology & $<5$ years & $2(12.5 \%)$ & & Male & $12(75.0 \%)$ & & $100 \%$ & $0(0.0 \%)$ & \\
\hline \multirow[t]{3}{*}{$16(30.1 \%)$} & $5-10$ years & $5(31.3 \%)$ & & Female & $4(25.0 \%)$ & & $50-100 \%$ & $3(18.8 \%)$ & \\
\hline & $11-20$ years & $1(6.3 \%)$ & & & & & $\begin{array}{l}\text { Less than } \\
50 \%\end{array}$ & $4(25.0 \%)$ & \\
\hline & $>20$ years & $8(50.0 \%)$ & & & & & $\begin{array}{l}\text { Less than } \\
25 \%\end{array}$ & $9(56.3 \%)$ & \\
\hline
\end{tabular}

Table 1) that were based on the most recent American Heart Association (AHA) and American College of Obstetricians and Gynecologists (ACOG) guidelines [13-16].

Descriptive analysis was used to examine the responses, and where applicable, the Fisher exact test was used to determine statistical differences; a $p$ value $\leq 0.05$ was considered significant. The gathered data were all categorical variables, which were initially organized into frequency distribution tables and then displayed using columnar graphs to highlight and calculate relative frequencies. Fisher's exact test was used to analyze differences in survey responses from different providers. All data was analyzed using Stata version 16.1 (StatCorp, College Station, TX, USA). All data collected for data analysis included only de-identified study 
information. Study was assessed by the institutional review board at University of Florida as consistent with a quality improvement initiative and exempt from further regulatory requirements. As responses were anonymous and voluntary and as it was deemed an initiative for quality review, the institutional review board considered the study to be exempt from further review.

\section{RESULTS}

The survey was sent to a total of 140 physicians, of whom $40(29 \%)$ worked in IM, $43(31 \%)$ in FM, 38 (27\%) in cardiology and 19 (13\%) in ObGyn. A total of 53 (38\%) physicians voluntarily participated in the anonymous survey, with a response rate according to speciality/field of $28 \%$ of physicians in IM, 33\% in FM, 39\% in cardiology and 63\% in Ob-Gyn. Survey respondent demographics and proportion of women patients are shown in Table 2. Of these 53 physicians, $11(21 \%)$ were in IM, $14(26 \%)$ in FM, 12 (23\%) in Ob-Gyn and 15 (30\%) were in cardiology. The total number of years of experience varied among each specialty, however, the majority of physicians had $>10$ years of clinical experience. A higher percentage of respondents in IM and Ob-Gyn were women (73 vs. $27 \%$ men in IM; 58 vs. $42 \%$ men in Ob-Gyn), whereas a higher percentage of respondents in cardiology were men (75 vs. $25 \%$ women). There was an equal number of male and female respondents within family medicine. As expected, $100 \%$ of the patients were women for ObGyn respondents compared to other specialties ( $p$ value $<0.0001)$. Cardiologists had the lowest percentage of female patients, with $81 \%$ of the physicians reporting fewer than 50\% women in their patient population. Respondents in both FM and IM reported that approximately $50-100 \%$ of their patients were women.

As shown in Fig. 1, the overwhelming majority of physicians aimed to screen their women patients for CVD risk factors, and although most physicians screen often or always for CVD risk factors, $21 \%$ of physicians reported only screening sometimes or never. When assessing CVD risk, the majority of physicians in the fields of IM, FM and cardiology did not often ask about APOs, in contrast to the Ob-Gyn physicians, among whom 42\% screened every woman and 58\% screened often) (Fig. 2). Comparing Ob-Gyn responses regarding screening often or always for APOs to the frequency of screening in the other fields, the difference was highly significant $(p<0.001)$ (Table 3).

Greater percentages of cardiology and ObGyn physicians were aware of the association between APOs and CVD, compared with IM and FM physicians (Fig. 3) although the results did not reach statistical significance ( $p$ value 0.107 )

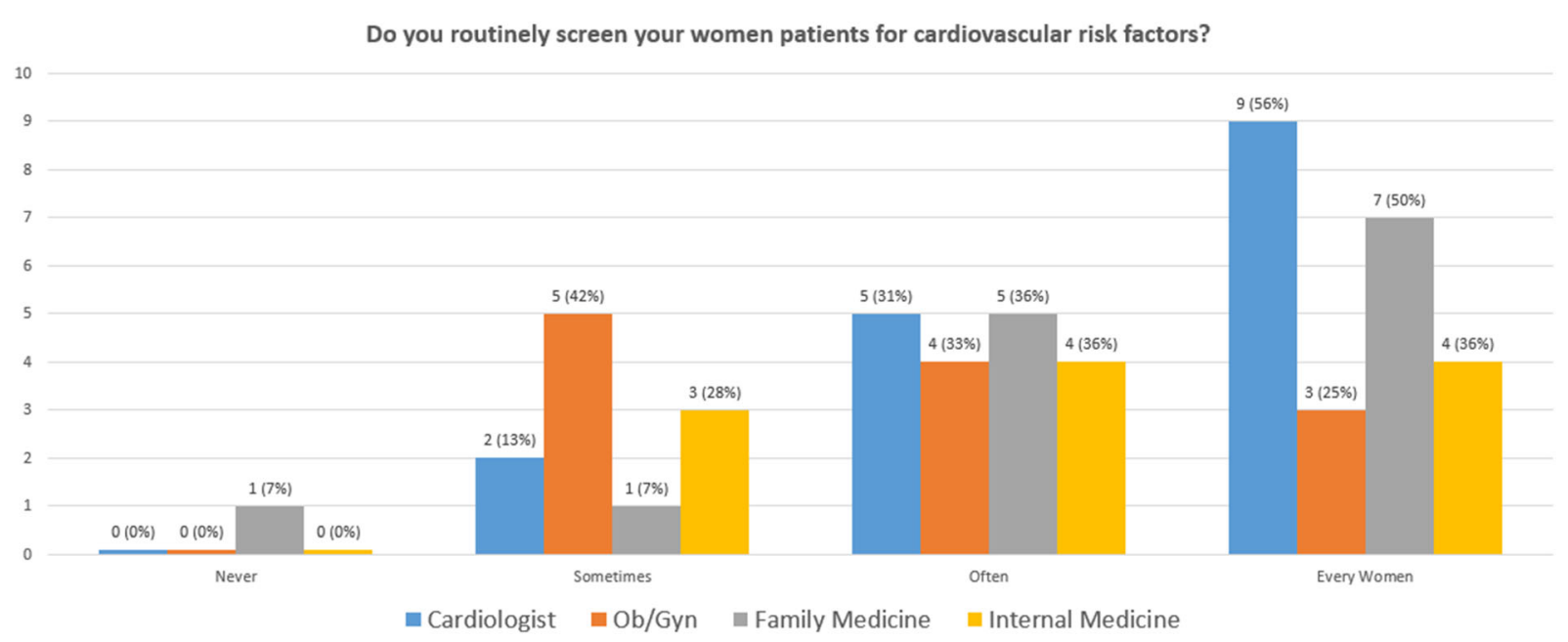

Fig. 1 Results of survey question 4: Do you routinely screen your women patients for cardiovascular risk factors? 


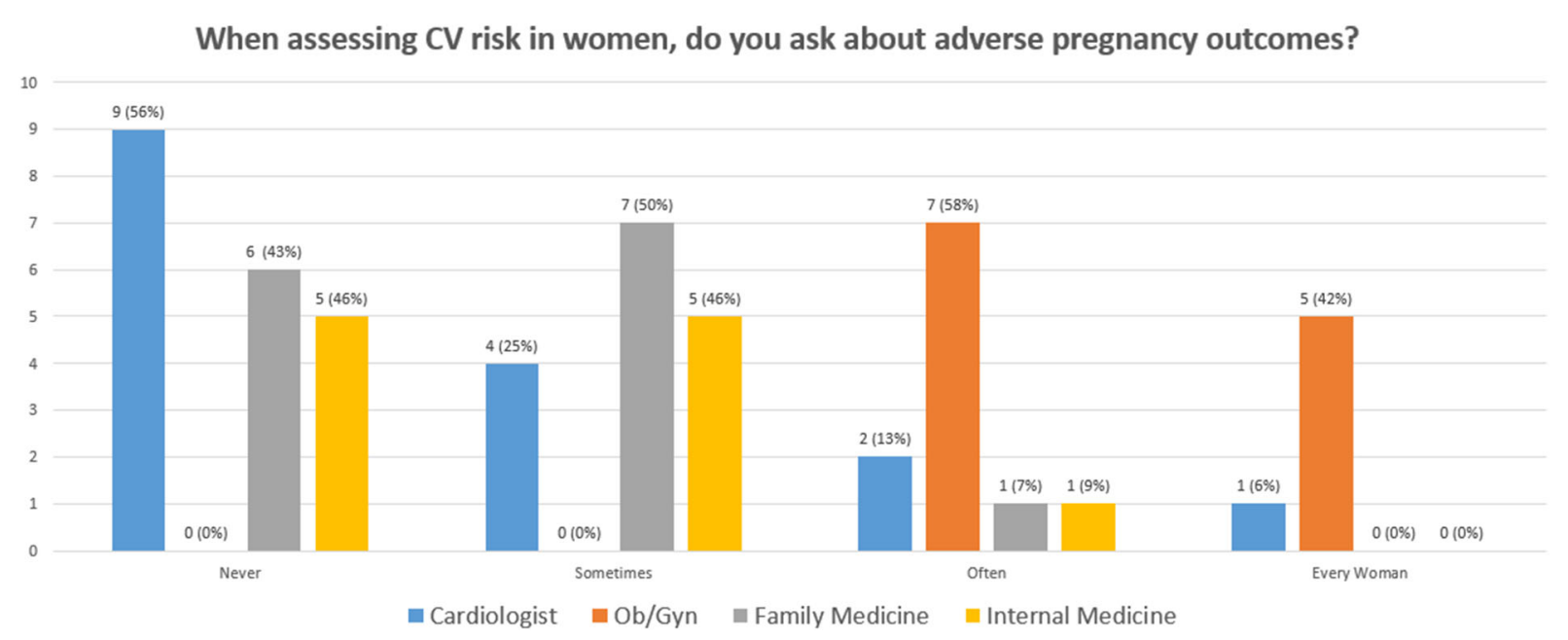

Fig. 2 Results of survey question 5: When assessing cardiovascular risk in women, do you ask about adverse pregnancy outcomes?

(Table 4). Although nearly $69 \%$ of cardiologists reported awareness of this association, 56\% never asked about APOs when assessing CVD risk (Figs. 2, 3).

Physicians from all specialties were aware that PE and GDM were APOs associated with maternal long-term CVD risk; however, PTB remained consistently under-recognized as being an APO (Tables 5, 6). Furthermore, there remains a lack of knowledge regarding diabetic screening guidelines for women with a history of GDM. The majority of physicians in IM, FM and cardiology incorrectly identified or reported not knowing the frequency at which these women should be screened for diabetes postpartum. Although Ob-Gyn physicians were more knowledgeable about the guidelines compared with physicians in other specialties, they still did not all correctly identify this recommended screening frequency. When assessed by specific APO type, there were no statistical differences in recognition of association with long-term CV risk by specialty (Table 6). There were no statistical differences by specialty regarding screening for diabetes (Table 7).

Within every specialty physicians recognized that women with a history of PE should have annual blood pressure measurement, but they were not aware of the importance of assessing the lipid profile, body mass index and glucose (Tables $8,9,10$ ). Physicians from all specialties recognized that women with a history of $\mathrm{PE}$ have an increased risk of developing chronic hypertension, stroke and ischemic heart disease; however, many providers were unaware of the associated risk of future heart failure and type 2 diabetes mellitus. Physicians in the fields of IM, FM and cardiology were only slightly familar or not at all familiar with the current AHA and/or ACOG guidelines concerning treatment and follow-up management of women with PE. The majority of Ob-Gyn physicians reported being very familiar with these guidelines (Fig. 4) (Table 11). This difference reached significance when comparing ObGyn physicians to those in other specialties $(p<0.0001)$.

\section{DISCUSSION}

Cardiovascular disease continues to be the leading cause of death in women worldwide [1-3]. In the past several decades, intensive research efforts have focused on modifying the risk of CVD and promoting primary prevention strategies. Sex-specific risk factors, particularly those related to pregnancy, are known to have accompanying risks for CVD [15, 16]. Vascular damage and placental dysfunction occurring during gestation may share some of the underlying mechanisms for future CVD or may be the 
Table 3 Screening for cardiovascular risk factors and adverse pregnancy outcomes

\begin{tabular}{|c|c|c|c|c|c|c|}
\hline \multirow[t]{2}{*}{ Specialty } & \multicolumn{2}{|c|}{$\begin{array}{l}\text { Question 4: Do you routinely } \\
\text { screen your women patients for } \\
\text { CV risk factors? }\end{array}$} & \multirow[t]{2}{*}{$p$ value } & \multicolumn{2}{|c|}{$\begin{array}{l}\text { Question 5: When assessing } \\
\text { CV risk in women, do you ask } \\
\text { about adverse pregnancy } \\
\text { outcomes? }\end{array}$} & \multirow[t]{2}{*}{$p$ value } \\
\hline & $\begin{array}{l}\text { Screening } \\
\text { frequency }\end{array}$ & $\begin{array}{l}\text { Respondents, } \\
N(\%)\end{array}$ & & $\begin{array}{l}\text { Screening } \\
\text { frequency }\end{array}$ & $\begin{array}{l}\text { Respondents, } \\
N(\%)\end{array}$ & \\
\hline \multirow{4}{*}{$\begin{array}{l}\text { Internal medicine (11 } \\
\text { respondents) }\end{array}$} & Every women & $4 / 11(36.4 \%)$ & \multirow[t]{16}{*}{0.446} & Every women & $0 / 11(0.0 \%)$ & \multirow[t]{16}{*}{$<0.0001$} \\
\hline & Often & $4 / 11(36.4 \%)$ & & Often & $1 / 11(9.1 \%)$ & \\
\hline & Sometimes & $3 / 11(27.2 \%)$ & & Sometimes & $5 / 11(45.5 \%)$ & \\
\hline & Never & $0 / 11(0 \%)$ & & Never & $5 / 11(45.5 \%)$ & \\
\hline \multirow{4}{*}{$\begin{array}{l}\text { Family medicine ( } 14 \\
\text { respondents) }\end{array}$} & Every women & $7 / 14(50.0 \%)$ & & Every women & $0 / 14(0.00 \%)$ & \\
\hline & Often & $5 / 14(35.7 \%)$ & & Often & $1 / 14(7.1 \%)$ & \\
\hline & Sometimes & $1 / 14(7.1 \%)$ & & Sometimes & $7 / 14(50.0 \%)$ & \\
\hline & Never & $1 / 14(7.1 \%)$ & & Never & $6 / 14(42.9 \%)$ & \\
\hline \multirow{4}{*}{$\begin{array}{l}\text { Obstetrics-Gynecology (12 } \\
\text { respondents) }\end{array}$} & Every women & $3 / 12(25.0 \%)$ & & Every women & $5 / 12(41.7 \%)$ & \\
\hline & Often & $4 / 12(33.3 \%)$ & & Often & $7 / 12(58.3 \%)$ & \\
\hline & Sometimes & $5 / 12(41.7 \%)$ & & Sometimes & $0 / 12(0.0 \%)$ & \\
\hline & Never & $0 / 12(0.0 \%)$ & & Never & $0 / 12(0.0 \%)$ & \\
\hline \multirow[t]{4}{*}{ Cardiology (16 respondents) } & Every women & $9 / 16(56.3 \%)$ & & Every women & $1 / 16(6.3 \%)$ & \\
\hline & Often & $5 / 16(31.3 \%)$ & & Often & $2 / 16(12.5 \%)$ & \\
\hline & Sometimes & $2 / 16(12.5 \%)$ & & Sometimes & $4 / 16(25.0 \%)$ & \\
\hline & Never & $0 / 16(0.0 \%)$ & & Never & $9 / 16(56.3 \%)$ & \\
\hline
\end{tabular}

trigger for alternative pathways of injury [6]. There is a sufficient body of evidence in recent literature to suggest that women with a history of APOs are more likely to develop CVD later in life than those without $[4,7-10,12]$. This offers a unique window of opportunity to properly screen for, identify and provide early intervention strategies in women with a history of APOs. However, whether sufficient knowledge exists within various specialties to facilitate screening is unknown. Through this study, we determined that physicians in the investigated specialties from an academic institution were not aware of the association between APOs and CVD, the various types of APOs or their associated secondary risk factors. In addition, there was a knowledge deficiency in screening frequencies and of guidelines for follow-up management for a given APO. Interestingly, in this study, physicians' knowledge regarding the associations between APO and CVD did not affect screening rates for CVD. A review of the most current AHA and ACOG guidelines recommends that all pregnancies involving PE, GDM and PTB need to be recognized as an APO, with the women at increased risk of developing type 2 diabetes mellitus, ischemic heart disease, chronic hypertension, stroke and heart failure [12-16]. These guidelines also suggest the need of an annual follow-up for blood pressure, lipids, fasting glucose and body mass index screening $[12,13,16]$. It is important to note, 


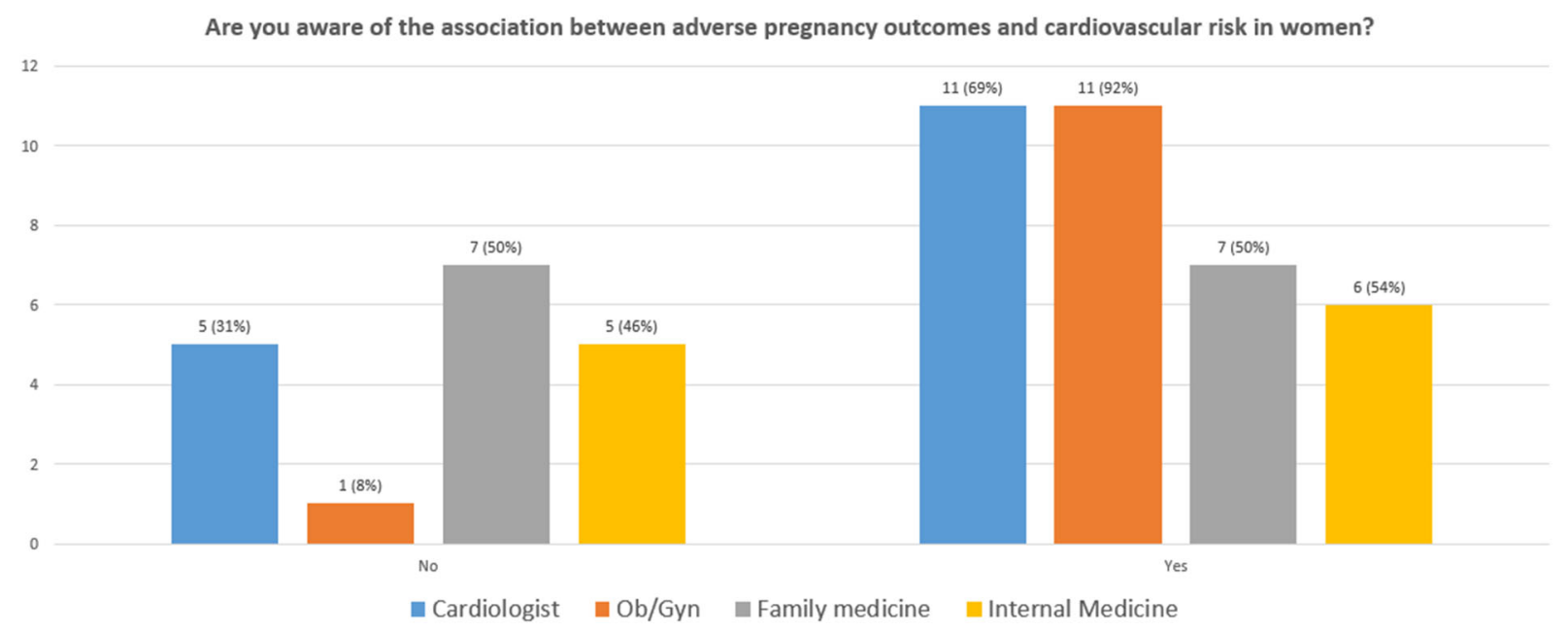

Fig. 3 Results of survey question 6: Are you aware of the association between adverse pregnancy outcomes and cardiovascular risk in women?

Table 4 Awareness of the association between adverse pregnancy outcomes and cardiovascular risk

\begin{tabular}{lll}
\hline Specialty & $\begin{array}{l}\text { Question 6:Are you } \\
\text { aware of the } \\
\text { association between } \\
\text { adverse pregnancy } \\
\text { outcomes and } \\
\text { cardiovascular risk } \\
\text { in women? }\end{array}$ \\
\cline { 2 - 2 } & $\begin{array}{l}\text { Yes/ Respondents, } \\
\text { no } \quad \text { N (\%) }\end{array}$ \\
\hline Internal medicine (11 & Yes $6(54.6 \%)$ & 0.107 \\
respondents) & No $5(45.5 \%)$ \\
Family medicine (14 & Yes $7(50.0 \%)$ \\
respondents) & No $7(50.0 \%)$ \\
Obstetrics-Gynecology & Yes $11(91.7 \%)$ \\
(12 respondents) & No $1(8.3 \%)$ \\
Cardiology (16 & Yes $11(68.8 \%)$ \\
respondents) & No $5(31.3 \%)$ \\
\hline
\end{tabular}

however, that the starting time and the frequency of follow-up differ amongst the international societies and associations [13].

APOs are likely familiar to and easily recognized by those physicians managing these complications, whereas to others not cognizant of these APOs, preventative measures for future CVD may be missed. Preterm birth is defined as a delivery at $<37$ weeks gestation, and sometimes the patient may not be aware of the precise gestational age at delivery. The distinction is important as those women with either spontaneous preterm birth at $<32$ weeks gestation, those delivered preterm for medical conditions or those with pre-eclampsia are at particularly higher risk for future composite CVD death (adjusted odds ratio 1.8) [11]. Other researchers have reported similar risks for future CVD as well as nearly a fourfold increased relative risk for hypertensive disease in those with a prior pregnancy complicated by pre-eclampsia [12].

Thus, the results of our survey suggest that an opportunity exists to raise physician awareness of APOs and to provide continuous medical education about APOs and their association with future CVD risk. Such knowledge has the potential to translate into educational initiatives targeted toward multi-disciplinary education on this topic as well as clear guidelines for screening women. Increasing awareness of these associations is a step towards improving identification of APOs as CVD risk factors, promoting risk reduction strategies and improving risk factor screening. This is particularly important in young women who have varied sources of primary care, such as those specialties assessed 
Table 5 Type of adverse pregnancy outcomes and screening for future secondary complications

\begin{tabular}{|c|c|c|}
\hline \multirow[t]{2}{*}{ Specialty } & \multicolumn{2}{|c|}{$\begin{array}{l}\text { Question 7: Which of the following is an adverse pregnancy outcome } \\
\text { associated w/maternal long term CV risk? May choose more than one }\end{array}$} \\
\hline & APO & Respondents, $N(\%)$ \\
\hline \multirow[t]{5}{*}{ Internal medicine (11 respondents) } & Pre-eclampsia & $11(100.0 \%)$ \\
\hline & Cervical insufficiency & $1(9.1 \%)$ \\
\hline & Gestational DM & $11(100.0 \%)$ \\
\hline & Preterm birth & $1(9.1 \%)$ \\
\hline & Post-partum hemorrhage & $2(18.2 \%)$ \\
\hline \multirow[t]{5}{*}{ Family medicine (14 respondents) } & Pre-eclampsia & $13(92.9 \%)$ \\
\hline & Cervical insufficiency & $0(0.0 \%)$ \\
\hline & Gestational DM & $14(100.0 \%)$ \\
\hline & Preterm Birth & $5(35.7 \%)$ \\
\hline & Post-partum hemorrhage & $2(14.3 \%)$ \\
\hline \multirow[t]{5}{*}{ Obstetrics-Gynecology (12 respondents) } & Pre-eclampsia & $12(100.0 \%)$ \\
\hline & Cervical insufficiency & $1(9.1 \%)$ \\
\hline & Gestational DM & $11(91.7 \%)$ \\
\hline & Preterm birth & $6(50.0 \%)$ \\
\hline & Post-partum hemorrhage & $2(16.7 \%)$ \\
\hline \multirow[t]{5}{*}{ Cardiology (16 respondents) } & Pre-eclampsia & $15(93.8 \%)$ \\
\hline & Cervical insufficiency & $1(6.3 \%)$ \\
\hline & Gestational DM & $14(87.5 \%)$ \\
\hline & Preterm birth & $5(31.3 \%)$ \\
\hline & Post-partum hemorrhage & $4(25.0 \%)$ \\
\hline
\end{tabular}

Text in bold are pre-specified responses that are based on the most recent AHA and ACOG guidelines [13-16] $A P O$ Adverse pregnancy outcome, $D M$ diabetes mellitus

in our study. Given that pregnancy often occurs in a woman's life before the onset of CVD symptoms, establishing proper screening for APOs affords opportunities for risk mitigation through lifestyle modification and pharmacotherapy for hypertension as well as lipidlowering therapies where indicated. Although conventional CVD risk calculators do not include consideration of APOs, the most recent primary prevention and lipid guidelines now include consideration of APOs as risk-enhancers for lipid therapy [6]. Thus, APOs continue to emerge as an important part of risk assessment, particularly in young, often otherwise healthy women, and knowledge of such a medical history can guide not only risk assessment but also risk modification. 
Table 6 Type of APOs and screening for future secondary complications according to APO

\begin{tabular}{llllll}
\hline APO & $\begin{array}{l}\text { Internal medicine } \\
\text { respondents })\end{array}$ & $\begin{array}{l}\text { Family medicine } \\
\text { respondents })\end{array}$ & $\begin{array}{l}\text { Obstetrics-Gynecology } \\
\text { (12 respondents) }\end{array}$ & $\begin{array}{l}\text { Cardiology (16 } \\
\text { respondents) }\end{array}$ & $\boldsymbol{p}$ value \\
\hline $\begin{array}{l}\text { Pre-eclampsia } \\
\text { Cervical }\end{array}$ & $11(100.0 \%)$ & $13(92.9 \%)$ & $12(100.0 \%)$ & $15(93.8 \%)$ & 1.000 \\
insufficiency & $1(9.1 \%)$ & $0(0.0 \%)$ & $1(9.1 \%)$ & $1(6.3 \%)$ & 0.780 \\
$\begin{array}{c}\text { Gestational } \\
\text { DM }\end{array}$ & $11(100.0 \%)$ & $14(100.0 \%)$ & $11(91.7 \%)$ & $14(87.5 \%)$ & 0.477 \\
$\begin{array}{c}\text { Preterm birth } \\
\begin{array}{c}\text { Post-partum } \\
\text { hemorrhage }\end{array}\end{array}$ & $1(9.1 \%)$ & $5(35.7 \%)$ & $6(50.0 \%)$ & $5(31.3 \%)$ & 0.219 \\
\hline
\end{tabular}

Values are presented as the number with the percentage in parentheses

Table 7 Type of APOs and screening for future secondary complications according to APO

\begin{tabular}{|c|c|c|c|}
\hline \multirow[t]{2}{*}{ Specialty } & \multicolumn{2}{|c|}{$\begin{array}{l}\text { Question 8: How often should women with a history of gestational } \\
\text { diabetes be screened for diabetes after delivery? }\end{array}$} & \multirow[t]{2}{*}{$p$ value } \\
\hline & Frequency of screening & Respondents, $N(\%)$ & \\
\hline \multirow[t]{4}{*}{ Internal medicine (11 respondents) } & Every 5 years & $0(0.0 \%)$ & 0.089 \\
\hline & Every 3 years & $2(18.2 \%)$ & \\
\hline & Every 1 year & $5(45.5 \%)$ & \\
\hline & I don't know & $4(36.4 \%)$ & \\
\hline \multirow[t]{4}{*}{ Family medicine ( 14 respondents) } & Every 5 years & $1(7.1 \%)$ & \\
\hline & Every 3 years & $2(14.3 \%)$ & \\
\hline & Every 1 year & $6(42.9 \%)$ & \\
\hline & I don't know & $5(35.7 \%)$ & \\
\hline \multirow[t]{4}{*}{ Obstetrics-Gynecology (12 respondents) } & Every 5 years & $0(0.0 \%)$ & \\
\hline & Every 3 years & $3(25.0 \%)$ & \\
\hline & Every 1 year & $9(75.0 \%)$ & \\
\hline & I don't know & $0(0.0 \%)$ & \\
\hline \multirow[t]{4}{*}{ Cardiology (16 respondents) } & Every 5 years & $4(25.0 \%)$ & \\
\hline & Every 3 years & $3(18.8 \%)$ & \\
\hline & Every 1 year & $4(25.0 \%)$ & \\
\hline & I don't know & $5(31.2 \%)$ & \\
\hline
\end{tabular}

Text in bold are pre-specified responses that are based on the most recent AHA and ACOG guidelines [13-16] 
Table 8 Identification and screening of complications associated with APOs and provider awareness of current guidelines

\begin{tabular}{|c|c|c|c|c|c|c|}
\hline \multirow[t]{2}{*}{ Specialty } & \multicolumn{2}{|c|}{$\begin{array}{l}\text { Question 9: Women with } \\
\text { history of pre-eclampsia } \\
\text { should have annual assessment } \\
\text { of which of the following? May } \\
\text { choose more than one. }\end{array}$} & \multicolumn{2}{|c|}{$\begin{array}{l}\text { Question 10: Women with a } \\
\text { history of pre-eclampsia have } \\
\text { an increased risk of } \\
\text { developing which of the } \\
\text { following? May choose more } \\
\text { than one. }\end{array}$} & \multicolumn{2}{|c|}{$\begin{array}{l}\text { Question 11: How familiar } \\
\text { are you with the current } \\
\text { AHA guidelines and/or } \\
\text { ACOG guidelines } \\
\text { concerning treatment and } \\
\text { follow-up management of } \\
\text { women with pre- } \\
\text { eclampsia? }\end{array}$} \\
\hline & $\begin{array}{l}\text { Clinical } \\
\text { parameter }\end{array}$ & $\begin{array}{l}\text { Respondents, } \\
N(\%)\end{array}$ & $\begin{array}{l}\text { Adverse } \\
\text { event }\end{array}$ & $\begin{array}{l}\text { Respondents, } \\
N(\%)\end{array}$ & Familiarity & $\begin{array}{l}\text { Respondents, } \\
N(\%)\end{array}$ \\
\hline \multirow[t]{7}{*}{$\begin{array}{l}\text { AInternal medicine (11 } \\
\text { respondents) }\end{array}$} & Lipid profile & $4(36.4 \%)$ & Type 2 DM & $2(18.2 \%)$ & $\begin{array}{l}\text { Very } \\
\text { familiar }\end{array}$ & $0(0 \%)$ \\
\hline & $\begin{array}{l}\text { Blood } \\
\text { pressure }\end{array}$ & $11(100.0 \%)$ & $\begin{array}{c}\text { Ischemic } \\
\text { heart } \\
\text { disease }\end{array}$ & 7 (63.6\%) & $\begin{array}{l}\text { Slightly } \\
\text { familiar }\end{array}$ & $5(45.5 \%)$ \\
\hline & BMI & $6(54.6 \%)$ & $\begin{array}{c}\text { Chronic } \\
\text { HTN }\end{array}$ & $11(100.0 \%)$ & $\begin{array}{r}\text { Not at all } \\
\text { familiar }\end{array}$ & $6(54.6 \%)$ \\
\hline & Glucose & $4(36.4 \%)$ & Stroke & $9(81.8 \%)$ & & \\
\hline & $\begin{array}{l}\text { Annual } \\
\text { mammogram }\end{array}$ & $1(9.1 \%)$ & Heart failure & $6(54.6 \%)$ & & \\
\hline & & & Arrhythmia & $1(9.1 \%)$ & & \\
\hline & & & Syncope & $0(0.0 \%)$ & & \\
\hline \multirow[t]{8}{*}{$\begin{array}{l}\text { Family medicine (14 } \\
\text { respondents) }\end{array}$} & Lipid profile & $6(42.9 \%)$ & Type 2 DM & $3(21.4 \%)$ & $\begin{array}{l}\text { Very } \\
\text { familiar }\end{array}$ & $0(0 \%)$ \\
\hline & $\begin{array}{l}\text { Blood } \\
\text { pressure }\end{array}$ & 14 & $\begin{array}{c}\text { Ischemic } \\
\text { heart } \\
\text { disease }\end{array}$ & $13(92.9 \%)$ & $\begin{array}{l}\text { Slightly } \\
\text { familiar }\end{array}$ & $4(28.6 \%)$ \\
\hline & & $-100.00 \%$ & $\begin{array}{c}\text { Chronic } \\
\text { HTN }\end{array}$ & $14(100.0 \%)$ & $\begin{array}{l}\text { Not at all } \\
\text { familiar }\end{array}$ & $10(71.4 \%)$ \\
\hline & BMI & 7 & Stroke & $8(57.1 \%)$ & & \\
\hline & & $-50.00 \%$ & Heart failure & $7(50.0 \%)$ & & \\
\hline & Glucose & 3 & Arrhythmia & $0(0 \%)$ & & \\
\hline & & $-21.40 \%$ & Syncope & $0(0 \%)$ & & \\
\hline & $\begin{array}{l}\text { Annual } \\
\text { mammogram }\end{array}$ & $0(0.0 \%)$ & & & & \\
\hline
\end{tabular}


Table 8 continued

\begin{tabular}{|c|c|c|c|c|c|c|}
\hline \multirow[t]{2}{*}{ Specialty } & \multicolumn{2}{|c|}{$\begin{array}{l}\text { Question 9: Women with } \\
\text { history of pre-eclampsia } \\
\text { should have annual assessment } \\
\text { of which of the following? May } \\
\text { choose more than one. }\end{array}$} & \multicolumn{2}{|c|}{$\begin{array}{l}\text { Question 10: Women with a } \\
\text { history of pre-eclampsia have } \\
\text { an increased risk of } \\
\text { developing which of the } \\
\text { following? May choose more } \\
\text { than one. }\end{array}$} & \multicolumn{2}{|c|}{$\begin{array}{l}\text { Question 11: How familiar } \\
\text { are you with the current } \\
\text { AHA guidelines and/or } \\
\text { ACOG guidelines } \\
\text { concerning treatment and } \\
\text { follow-up management of } \\
\text { women with pre- } \\
\text { eclampsia? }\end{array}$} \\
\hline & $\begin{array}{l}\text { Clinical } \\
\text { parameter }\end{array}$ & $\begin{array}{l}\text { Respondents, } \\
N(\%)\end{array}$ & $\begin{array}{l}\text { Adverse } \\
\text { event }\end{array}$ & $\begin{array}{l}\text { Respondents, } \\
N(\%)\end{array}$ & Familiarity & $\begin{array}{l}\text { Respondents, } \\
N(\%)\end{array}$ \\
\hline \multirow[t]{7}{*}{$\begin{array}{l}\text { Obstetrics-Gynecology } \\
\text { (12 respondents) }\end{array}$} & Lipid profile & $8(66.7 \%)$ & Type 2 DM & $6(50.0 \%)$ & $\begin{array}{l}\text { Very } \\
\text { familiar }\end{array}$ & $7(58.3 \%)$ \\
\hline & $\begin{array}{l}\text { Blood } \\
\text { pressure }\end{array}$ & $12(100.0 \%)$ & $\begin{array}{c}\text { Ischemic } \\
\text { heart } \\
\text { disease }\end{array}$ & $11(91.7 \%)$ & $\begin{array}{l}\text { Slightly } \\
\text { familiar }\end{array}$ & $4(33.3 \%)$ \\
\hline & BMI & $10(83.3 \%)$ & $\begin{array}{c}\text { Chronic } \\
\text { HTN }\end{array}$ & $12(100.0 \%)$ & $\begin{array}{r}\text { Not at all } \\
\text { familiar }\end{array}$ & $1(8.3 \%)$ \\
\hline & Glucose & $7(58.3 \%)$ & Stroke & $9(75.0 \%)$ & & \\
\hline & $\begin{array}{l}\text { Annual } \\
\text { mammogram }\end{array}$ & $0(0.0 \%)$ & Heart failure & $10(83.3 \%)$ & & \\
\hline & & & Arrhythmia & $2(16.7 \%)$ & & \\
\hline & & & Syncope & $2(16.7 \%)$ & & \\
\hline \multirow[t]{7}{*}{$\begin{array}{l}\text { Cardiology }(16 \\
\text { respondents })\end{array}$} & Lipid profile & $5(31.3 \%)$ & Type 2 DM & $4(25.0 \%)$ & $\begin{array}{l}\text { Very } \\
\text { familiar }\end{array}$ & $0(0 \%)$ \\
\hline & $\begin{array}{l}\text { Blood } \\
\text { pressure }\end{array}$ & $16(100.0 \%)$ & $\begin{array}{c}\text { Ischemic } \\
\text { heart } \\
\text { disease }\end{array}$ & $13(82.8 \%)$ & $\begin{array}{l}\text { Slightly } \\
\text { familiar }\end{array}$ & $5(31.3 \%)$ \\
\hline & BMI & $6(37.5 \%)$ & $\begin{array}{c}\text { Chronic } \\
\text { HTN }\end{array}$ & $15(93.8 \%)$ & $\begin{array}{l}\text { Not at all } \\
\text { familiar }\end{array}$ & $11(68.8 \%)$ \\
\hline & Glucose & $5(31.3 \%)$ & Stroke & $11(68.8 \%)$ & & \\
\hline & $\begin{array}{l}\text { Annual } \\
\text { mammogram }\end{array}$ & $0(0.0 \%)$ & Heart failure & $9(56.8 \%)$ & & \\
\hline & & & Arrhythmia & $2(12.5 \%)$ & & \\
\hline & & & Syncope & $1(6.3 \%)$ & & \\
\hline
\end{tabular}

Text in bold are pre-specified responses that are based on the most recent AHA and ACOG guidelines [13-16] 
Table 9 Question 9: Women with history of pre-eclampsia should have annual assessment of which of the following? May choose more than one

\begin{tabular}{llllll}
\hline $\begin{array}{l}\text { Clinical } \\
\text { parameter }\end{array}$ & $\begin{array}{l}\text { Internal medicine } \\
\text { (11 respondents), } \\
\boldsymbol{N}(\%)\end{array}$ & $\begin{array}{l}\text { Family medicine (14 } \\
\text { respondents), } \boldsymbol{N}(\mathbf{\%})\end{array}$ & $\begin{array}{l}\text { Obstetrics-Gynecology } \\
(\mathbf{1 2} \text { respondents), } \boldsymbol{N}(\%)\end{array}$ & $\begin{array}{l}\text { Cardiology }(\mathbf{1 6} \\
\text { respondents) } \\
\boldsymbol{N}(\%)\end{array}$ & $\boldsymbol{p}$ value \\
\hline Lipid profile & $4(36.4 \%)$ & $6(42.9 \%)$ & $8(66.7 \%)$ & $5(31.3 \%)$ & 0.315 \\
Blood pressure & $11(100.0 \%)$ & $14(100 \%)$ & $12(100.0 \%)$ & $16(100.0 \%)$ & 1.000 \\
BMI & $6(54.6 \%)$ & $7(50 \%)$ & $10(83.3 \%)$ & $6(37.5 \%)$ & 0.107 \\
Glucose & $4(36.4 \%)$ & $3(21.4 \%)$ & $7(58.3 \%)$ & $5(31.3 \%)$ & 0.273 \\
$\begin{array}{l}\text { Annual } \\
\text { mammogram }\end{array}$ & $1(9.1 \%)$ & $0(0.0 \%)$ & $0(0.0 \%)$ & $0(0.0 \%)$ & 0.208 \\
\hline
\end{tabular}

Table 10 Question 10: Women with a history of pre-eclampsia have an increased risk of developing which of the following? May choose more than one

\begin{tabular}{lllcrl}
\hline $\begin{array}{l}\text { Clinical } \\
\text { parameter }\end{array}$ & $\begin{array}{l}\text { Internal medicine } \\
(\mathbf{1 1}), \boldsymbol{N}(\mathbf{\%})\end{array}$ & $\begin{array}{l}\text { Family medicine } \\
(\mathbf{1 4}), \boldsymbol{N}(\mathbf{\%})\end{array}$ & $\begin{array}{l}\text { Obstetrics-Gynecology } \\
(\mathbf{1 2}), \boldsymbol{N}(\mathbf{\%})\end{array}$ & $\begin{array}{l}\text { Cardiology (16), } \boldsymbol{p} \text { value } \\
\boldsymbol{N}(\%)\end{array}$ \\
\hline Type 2 DM & $2(18.2 \%)$ & $3(21.4 \%)$ & $6(50.0 \%)$ & $4(25.0 \%)$ & 0.347 \\
$\begin{array}{l}\text { Ischemic heart } \\
\quad 7(63.6 \%)\end{array}$ & $13(92.9 \%)$ & $11(91.7 \%)$ & $13(82.8 \%)$ & 0.245 \\
disease & & & & & \\
Chronic HTN & $11(100.0 \%)$ & $14(100.0 \%)$ & $12(100.0 \%)$ & $15(93.8 \%)$ & 1.000 \\
Stroke & $9(81.8 \%)$ & $8(57.1 \%)$ & $9(75.0 \%)$ & $11(68.8 \%)$ & 0.624 \\
Heart failure & $6(54.6 \%)$ & $7(50.0 \%)$ & $10(83.3 \%)$ & $9(56.8 \%)$ & 0.303 \\
Arrhythmia & $1(9.1 \%)$ & $0(0 \%)$ & $2(16.7 \%)$ & $2(12.5 \%)$ & 0.523 \\
Syncope & $0(0.0 \%)$ & $0(0 \%)$ & $2(16.7 \%)$ & $1(6.3 \%)$ & 0.313 \\
\hline
\end{tabular}

\section{Limitations}

The current study has a numbe of limitations. First, in this preliminary study, the sample size is small, thus the results are exploratory. Second, the responses to our questionnaire were voluntary, thus introducing potential bias. Mean age of the patients seen by different providers was not queried which may influence provider risk assessment. Additionally, this was a single-center study and results may not be applicable to other institutions.

\section{CONCLUSIONS}

In conclusion, our survey identifies a need for more education on recognizing the association between APOs and future maternal CVD risk within all specialties providing preventative care to women, especially among physicians in cardiology, IM and FM. Education on the importance of obtaining a detailed pregnancy history at each patient encounter, regardless of specialty, is needed to better assess a woman's overall CVD risk. In addition to education, developing reminders on electronic medical records (EMRs) would improve a physician's 


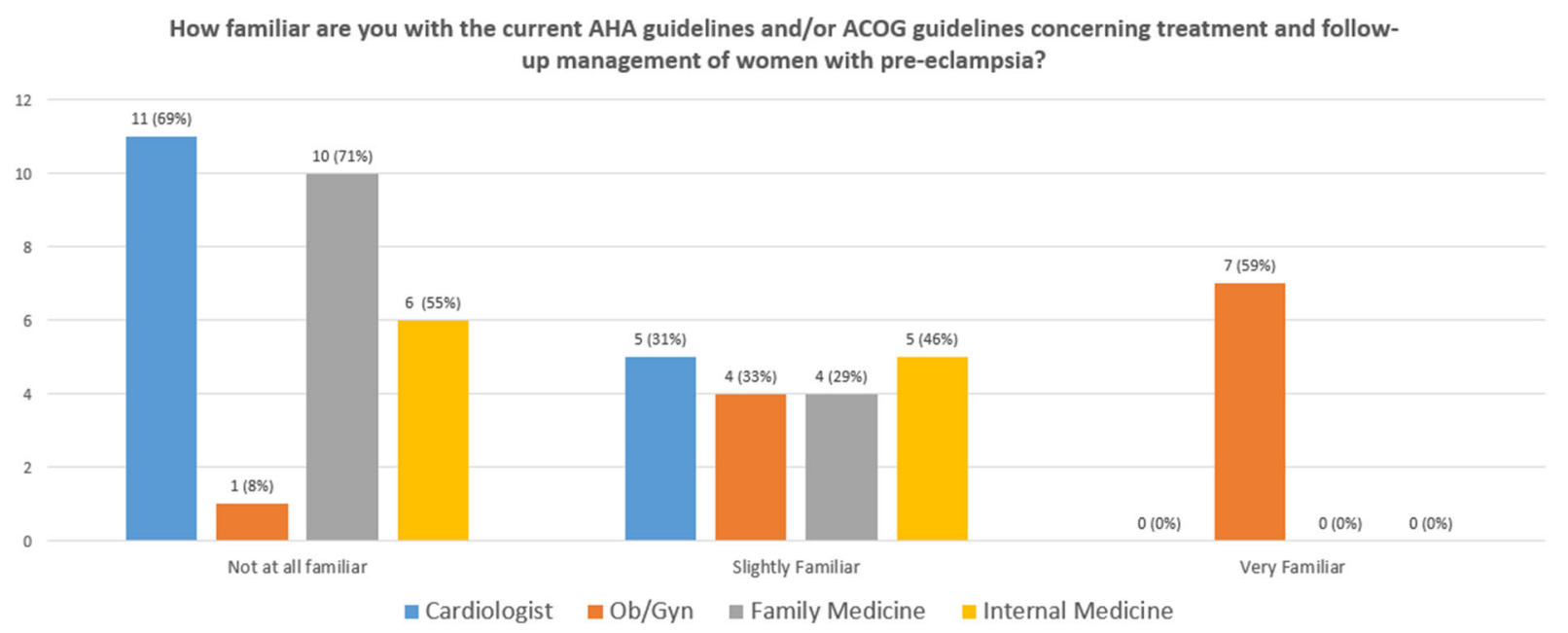

Fig. 4 Results of survey question 11: How familiar are you with the current AHA guidelines and/or ACOG guidelines concerning treatment and follow-up management of women with pre-eclampsia?

Table 11 Question 11: How familiar are you with the current AHA guidelines and/or ACOG guidelines concerning treatment and follow-up management of women with pre-eclampsia?

\begin{tabular}{llcc}
\hline Specialty & $\begin{array}{l}\text { Question 11: How familiar are you with the current AHA } \\
\text { guidelines and/or ACOG guidelines concerning treatment and } \\
\text { follow-up management of women with pre-eclampsia? }\end{array}$ & $\boldsymbol{p}$ value \\
\cline { 2 - 3 } & Familiarity & $\boldsymbol{N}(\%)$ & $<0.0001$ \\
\hline Internal medicine (11 respondents) & Very familiar & $0(0 \%)$ & $5(45.5 \%)$ \\
& Slightly familiar & $6(54.6 \%)$ \\
Family medicine (14 respondents) & Not at all familiar & Very familiar & $0(0 \%)$ \\
& Slightly familiar & $4(28.6 \%)$ \\
& Not at all familiar & $10(71.4 \%)$ \\
Obstetrics-Gynecology (12 respondents) & Very familiar & $7(58.3 \%)$ \\
& Slightly familiar & $4(33.3 \%)$ \\
& Not at all familiar & $1(8.3 \%)$ \\
& Very familiar & $0(0 \%)$ \\
& Slightly familiar & $5(31.3 \%)$ \\
& Not at all familiar & $11(68.8 \%)$ \\
\hline
\end{tabular}

awareness of and screening for APOs. Despite some raised concerns of alert fatigue, numerous studies have shown the effectiveness of EMR reminders in the improvement of awareness and screening rates of various medical conditions [17-19]. Ultimately, a combination of educational initiatives and EMR reminders should contribute to the strive toward better 
identifying women with APOs and modifiable risk factors to reduce CVD risk.

\section{ACKNOWLEDGEMENTS}

Funding. No funding or sponsorship was received for this study or publication of this article.

Authorship. All named authors meet the International Committee of Medical Journal Editors (ICMJE) criteria for authorship for this article, take responsibility for the integrity of the work as a whole, and have given their approval for this version to be published.

Authorship Contributions. All authors equally participated in the conception, distribution, analysis, statistical review and manuscript preparation.

Disclosures. All authors declare that they have no conflict of interest.

Compliance with Ethics Guidelines. All data collected for data analysis included only deidentified study information. The study was assessed by the institutional review board at the University of Florida as consistent with a quality improvement initiative and exempt from further regulatory requirements. As responses were anonymous and voluntary and as it was deemed an initiative for quality review, the institutional review board considered the study to be exempt from further review.

Data Availability. The datasets generated during and/or analyzed during the current study are available from the corresponding author on reasonable request.

Open Access. This article is licensed under a Creative Commons Attribution-NonCommercial 4.0 International License, which permits any non-commercial use, sharing, adaptation, distribution and reproduction in any medium or format, as long as you give appropriate credit to the original author(s) and the source, provide a link to the Creative Commons licence, and indicate if changes were made. The images or other third party material in this article are included in the article's Creative Commons licence, unless indicated otherwise in a credit line to the material. If material is not included in the article's Creative Commons licence and your intended use is not permitted by statutory regulation or exceeds the permitted use, you will need to obtain permission directly from the copyright holder. To view a copy of this licence, visit http://creativecommons.org/licenses/by$\mathrm{nc} / 4.0 /$.

\section{REFERENCES}

1. Lane-Cordova AD, Khan SS, Grobman WA, Grenland $\mathrm{P}$, Shah SJ. Long-term cardiovascular risks associated with adverse pregnancy outcomes. J Am Coll Cardiol. 2019;73(16):2106-16.

2. Mozaffarian D, Benjamin EJ, Go AS, et al. Heart disease and stroke statistics_-2015 update: a report from the American Heart Association. Circulation. 2015;131(4):e29-322.

3. Virani SS, Alonso A, Benjamin EJ, et al. Heart disease and stroke statistics-2020 update: a report from the American Heart Association. Circulation. 2020;141(9):e139-596.

4. Hauspurg A, Ying W, Hubel CA, Michos ED, Ouyang P. Adverse pregnancy outcomes and future maternal cardiovascular disease. Clin Cardiol. 2018;41(2):239-46.

5. Wu P, Haththotuwa R, Kwok CS, et al. Preeclampsia and future cardiovascular health: a systematic review and meta-analysis. Circ Cardiovasc Qual Outcomes. 2017;10(2):

6. Wu P, Mamas MA, Gulati M. Pregnancy as a predictor of maternal cardiovascular disease: the era of CardioObstetrics. J Womens Health (Larchmt). 2019;28(8):1037-50.

7. Wilkins-Haug L, Celi A, Thomas A, Frolkis J, Seely EW. Recognition by women's health care providers of long-term cardiovascular disease risk after preeclampsia. Obstet Gynecol. 2015;125(6): 1287-92.

8. Young B, Hacker MR, Rana S. Physicians' knowledge of future vascular disease in women with preeclampsia. Hypertens Preg. 2012;31(1):50-8. 
9. Heidrich M-B, Wenzel D, von Kaisenberg CS, Schippert C, von Versen-Höynck FM. Preeclampsia and long-term risk of cardiovascular disease: what do obstetrician-gynecologists know? BMC Preg Childb. 2013;13:61.

10. Grundy SM, Stone NJ, Bailey AL, et al. 2018 AHA/ ACC/AACVPR/AAPA/ABC/ACPM/ADA/AGS/APhA/ ASPC/NLA/PCNA guideline on the management of blood cholesterol: a report of the American College of Cardiology/American Heart Association task force on clinical practice guidelines. Circulation. 2019;139(25):e1082-143.

11. Wu P, Gulati M, Kwok CS, et al. Preterm delivery and future risk of maternal cardiovascular disease: a systematic review and meta-analysis. J Am Heart Assoc. 2018;7(2):

12. Bellamy L, Casas JP, Hingorani AD, Williams DJ. Pre-eclampsia and risk of cardiovascular disease and cancer in later life: systematic review and metaanalysis. BMJ. 2007;335(7627):974.

13. Benschop L, Duvekot JJ, van Lennep JER. Future risk of cardiovascular disease risk factors and events in women after a hypertensive disorder of pregnancy. Heart. 2019;105:1273-8.

14. Whelton PK, Carey RM, Aronow WS, et al. 2017 ACC/AHA/AAPA/ABC/ACPM/AGS/APhA/ASH/ ASPC/NMA/PCNA guideline for the prevention, detection, evaluation, and management of high blood pressure in adults: a report of the American College of Cardiology/American Heart Association Task Force on Clinical Practice Guidelines. Hypertension. 2018;71(6):e13-115.

15. Mosca L, Benjamin EJ, Berra K, et al. Effectivenessbased guidelines for the prevention of cardiovascular disease in women-2011 update: a guideline from the American Heart Association. Circulation. 2011;123:1243-62.

16. Mosca L, Grundy SM, Judelson D, et al. Guide to preventive cardiology for women: AHA/ACC Scientific Statement Consensus panel statement. Circulation. 1999;99:2480-4.

17. Chaudhry R, Scheitel SM, McMurtry EK, et al. Webbased proactive system to improve breast cancer screening: a randomized controlled trial. Arch Intern Med. 2007;167(6):606-11.

18. DeJesus RS, Angstman KB, Kesman R, et al. Use of a clinical decision support system to increase osteoporosis screening. J Eval Clin Pract. 2012;18(1): 89-92.

19. Chaudhry R, Tulledge-Scheitel SM, Parks DA, Angstman KB, Decker LK, Stroebel RJ. Use of a webbased clinical decision support system to improve abdominal aortic aneurysm screening in a primary care practice. J Eval Clin Pract. 2012;18(3):666-70. 